\title{
Mitigasi Intoleransi dan Radikalisme Beragama di Pondok Pesantren Melalui Pendekatan Pembelajaran Inklusif
}

\author{
Muhamad Ridwan Effendi \\ Universitas Negeri Jakarta, Indonesia \\ muhamad.ridwan@unj.ac.id.
}

DOI: https://doi.org/10.52593/pdg.01.1.05

Naskah diterima: 4 Januari 2020, direvisi: 16 April 2020, disetujui: 19 Juni 2020

\begin{abstract}
Abstraksi
Berdasarkan hasil penelitian Wahid Foundation, Yenny Wahid di tengah kegiatan workshop desa inklusi di Grage Hotel Cirebon yang bekerja sama dengan Komunitas Gerakan Desa Membangun (GDM) pada tahun 2016 lalu, menyampaikan bahwa kecenderungan masyarakat dalam berpandangan dan berperilaku intoleran yang dibungkus atas nama agama terus meningkat, terlebih hal itu dibuktikan dengan adanya rilis beberapa media yang menyebutkan bahwa provinsi Jawa Barat menjadi salah satu provinsi dengan kasus intoleransi dan radikalisme tertinggi di Indonesia. Sebagai provinsi dengan mayoritas penduduknya beragama Islam ditambah dengan banyaknya lembaga pendidikan pesantren, jelas hal ini kontra produktif. Dalam kajiannya ini, penelitian ini ingin menunjukkan bagaimana proses pembelajaran atau pendidikan pada pondok pesantren dalam merespon wacana intoleransi dan radikalisme atas nama agama agar dapat menepis pondok pesantren itu dianggap sebagai "sarang teroris". Melalui metode kualitatif dan pendekatan lapangan yang dilakukan pada pondok pesantren Al-Asy'ariyah Wanayasa dan ponpok pesantren Nurul Jadid Bojong ini diuraikan bahwa masih terdapat pandangan dalam pondok pesantren yang belum siap menerima dan memproses pembelajaran dengan pendekatan inklusif sehingga hal ini memberikan dampak pada pemahaman keagamaan yang belum cukup terbuka.
\end{abstract}

Kata Kunci : Intoleransi, Radikalisme, Inklusif, Pembelajaran, Pesantren

\section{A. Pendahuluan}

Perbincangan tentang radikalisme dan intoleransi dalam beragama kembali mengemuka belakangan ini. Seperti yang dilansir beberapa media ${ }^{1}$ beberapa waktu lalu menyebutkan bahwa provinsi Jawa Barat menjadi salah satu provinsi dengan kasus intoleransi dan radikalisme tertinggi di Indonesia. Kecenderungan masyarakat dalam berpandangan dan berperilaku intoleran yang dibungkus atas nama agama terus meningkat, hal itu disampaikan Yenny Wahid saat kegiatan workshop desa inklusi di Grage Hotel Cirebon. Hal ini berdasarkan hasil survey Wahid Foundation yang bekerja sama dengan Gerakan Desa Membangun (GDM) dalam melakukan kampanye perdamaian di masyarakat akar rumput pada tahun 2016 lalu yang menggunakan pendekatan multi-stage random sampling dengan perkiraan margin error 2,6\% dan tingkat keyakinan 95\% dari 1.520 responden yang tersebar di Indonesia.

\footnotetext{
${ }^{1}$ Hussein Ali, Jawa Barat Jadi Provinsi Tertinggi Kasus Radikalisme dan Intoleransi, Radar Cirebon, Edisi 10 Agustus 2016. dan M. Fauzan, Jawa Barat Peringkat Satu Kasus Intoleransi, Elshinta.com tanggal 10 Agustus 2016
} 
Dari isu tersebut, diskursus intoleransi dan radikalisme menjadi menarik ketika gambaran tersebut bertolak belakang dengan sosio-kultur masyarakat Jawa Barat sebagai masyarakat beragama yang notabenenya banyak berdiri lembaga-lembaga pendidikan keagamaan yang memberikan wadah pengetahuan dan pemahaman keagamaan masyarakat, salah satunya adalah pondok pesantren (selanjutnya disebut pesantren).

Kendatipun tidak secara langsung menyebut pesantren, akan tetapi fenomena tersebut menjadi sorotan serius, bagaimana tidak Jawa Barat yang mayoritas penduduknya merupakan muslim, berdasarkan penelitian tersebut dikatakan memiliki kecenderungan tingkat intoleransi beragama paling tinggi di antara daerah-daerah di Indonesia lainnya. Hal ini menarik untuk di kaji lebih jauh, mengingat Jawa Barat merupakan provinsi dengan jumlah ulama dan lembaga-lembaga pendidikan Islam terbanyak di Indonesia terlebih lembaga pesantren. Tentunya keberadaan ulama dan lembaga pesantren tersebut seharusnya memiliki peran dan pengaruh terhadap perubahan struktur sosial di masyarakat Jawa Barat khususnya dalam kontrol sosial masyarakat.

Bahkan anggapan ekstrimis yang cenderung melawan arus pun muncul ke permukaan dengan menyebut bahwa pesantren diduga menjadi tempat untuk memberikan doktrin agama yang cenderung mampu menumbuhkan benih-benih tindakan intoleransi, radikalisme dan/ atau ekstremisme di dalam ruang publik. Tentunya hal tersebut tidak seutuhnya benar dan cenderung memojokan, sebab pesantren dianggap sebagai pangkal dari paham keislaman yang eksklusif dan kontra produktif dengan semangat Islam yang Rahmatan lil 'Alamin.

Banyak manuver gerakan sosial keagamaan yang juga ikut menghangatkan diskursus tentang pesantren tersebut baik secara langsung maupun tidak langsung dikaitkan atau mengaitkan dengan pesantren. Terutama pasca terulangnya berbagai aksi kekerasan dalam bentuk radikalisme, ekstremisme dan terorisme atas nama agama. Sebut saja aksi kekerasan atas nama agama yang terjadi di beberapa kota di Jawa Barat seperti kasus ucapan sampurasun, pengrusakan dan/ atau pembakaran patung di kabupaten Purwakarta beberapa waktu lalu, kasus bom bunuh diri di Cirebon pada tahun 2011, kasus bom bunuh di kantor Mapoplres Medan sampai pada gerakan ISIS (Islamic State Iraq and Syria) yang telah memberikan pengaruh luar biasa bagi Indonesia. Pasalnya, mereka yang terlibat mengaku dirinya sebagai santri pesantren dan mengklaim tindakan-tindakan demikian yang terjadi di ruang publik sebagai wujud perjuangan agar tegaknya panjipanji Islam.

Di lain hal, adanya isu pesantren yang tidak lagi relevan dengan semangat perubahan zaman menambah daftar beban yang mesti dipikul oleh pesantren itu sendiri. Sebagai sebuah produk peradaban yang berfungsi sebagai wahana pendidikan dan sosialisasi bagi masyarakat agar dapat terus memiliki eksistensi dalam budayanya, pesantren senantiasa harus dapat melakukan penyesuaian di berbagai aspeknya melalui pembaharuan baik dalam bidang kurikulum pendidikan, pemberdayaan potensi lingkungan maupun tradisi dalam rangka menghadapi wacana tantangan pemikiran keagamaan berupa intoleransi dan radikalisme atas nama agama. 
Tidak ada asap kalau tidak ada api, begitu kira-kira untuk dapat menggambarkan isu di atas, menjadi suatu isyarat tentang perlu dan pentingnya studi lebih lanjut terkait keberadaan pesantren di tengah-tengah masyarakat dalam konteks kekinian. Tidak mungkin paradigma pendidikan zaman agraris diterapkan pada zaman industri. Ibarat memberi terapi, maka obat yang diberikan harus sesuai kenyataan obyektif penyakitnya. Karenanya, pendidikan harus menyesuaikan diri dengan problematika yang dihadapi masyarakatnya. Maka di sinilah peran pesantren dituntut untuk selalu beradaptasi agar penyelenggaraan pendidikannya relevan dengan zaman yang ada. Pemikiran inilah yang dimakud oleh Ali bin Abi Thalib ra. "Didiklah anak-anakmu sesuai dengan zamannya, karena mereka adalah generasi baru dan bukan generasi tatkala kamu dididik". ${ }^{2}$ Maksud serupa seperti yang dikuatkan oleh Ilmuan futuristik kebangsaan Amerika, Alvin Toffler, yang mengatakan; "education must shift into the future tense." ${ }^{3}$

Kehadiran pesantren di tengah masyarakat tentunya tidak hanya sebagai lembaga pendidikan, tetapi juga sebagai lembaga penyiaran agama dan sosial keagamaan. Selama masa kolonial, pesantren merupakan lembaga pendidikan yang paling banyak berhubungan dengan rakyat, tidak berlebihan kiranya untuk mengatakan pesantren sebagai lembaga pendidikan Grass Root People yang sangat menyatu dengan mereka. ${ }^{4}$

Sebagai lembaga pendidikan Islam, menurut Mastuhu ${ }^{5}$ pesantren telah eksis di tengah masyarakat selama enam abad (mulai abad ke-15 hingga sekarang) dan sejak awal berdirinya pesantren pernah menjadi satu-satunya institusi pendidikan milik pribumi yang memberikan kontribusi sangat besar dalam membentuk masyarakat melek huruf (Literacy) dan melek budaya (Cultural Literacy). Salah satu yang menonjol dari ajaranajaran yang dikembangkan oleh pesantren-pesantren di awal perkembangannya adalah kuatnya pola adaptasi dengan budaya lokal yang syarat dengan nilai-nilai toleransi. Atau setidaknya telah mampu menampilkan wajah Islam yang moderat dan tidak suka dengan kekerasan.

Namun demikian, akhir-akhir ini, watak adaptif dan toleran semacam ini tampak meredup. Hal ini disebabkan oleh adanya sejumlah aksi terror dan kekerasan yang marak terjadi di Indonesia beberapa tahun belakangan ini, dilakukan oleh beberapa pelaku yang nota bene alumni pesantren. Sebagian kemudian menggeneralisir bahwa pesantren adalah the breeding ground yang mencetak santri yang tidak toleran terhadap perbedaan.

Tentunya tantangan pesantren saat ini sangat berat, ia dituntut mampu memberikan pengembangan kualitas pemikiran bagi santri dan masyarakat. Hal ini dikarenakan kedudukan pesantren tidak dapat dipisahkan dari kehidupan masyarakat, bahkan satu sama lain saling mempengaruhi guna memberikan kontribusi pemikiran dan pemberdayaan yang lebih kuat. Kemampuannya dalam menjaga nilai primordial secara

\footnotetext{
${ }^{2}$ Malik Fadjar, Visi Pembaruan Pendidikan Islam (Jakarta: LP3NI, 1998), 28.

${ }^{3}$ Ibid.

${ }^{4}$ Wahjoetomo, Perguruan Tinggi Pesantren, Pendidikan Alternatif Masa Depan, (Jakarta: Gema Insani Press, 1997), 90.

${ }^{5}$ Mastuhu, Dinamika Sistem Pendidikan Pesantren, (Jakarta: INIS, 1997), 21.
} 
swadaya membuat lembaga ini menjadi satu-satunya lembaga pendidikan yang mampu bertahan dan memposisikan diri sebagai aktor penting terhadap penyebaran nilai-nilai keislaman dalam pranata sosial di masyarakat.

Tantangan seperti untuk merubah paradigma berpikir manusia dari sikap-sikap eksklusif menuju inklusif, permusuhan menjadi persaudaraan merupakan sebagian tantangan yang dihadapi pesantren dalam mengembangkan kualitas pendidikannya, karena menurut Ahmad Ludjito, ${ }^{6}$ pada hakekatnya pendidikan adalah suatu proses dari "upaya memanusiakan manusia". Hal Ini mengandung maksud bahwa tanpa adanya media berupa pendidikan maka teologi plural akan sulit berkembang di negara ini. Pendidikan dan ilmu pengetahuan adalah sesuatu yang agung karena dengan pendidikan kita, dapat membuka cakrawala untuk melihat kenyataan yang terjadi dalam masyarakat. Termasuk di dalamnya keragaman atau heterogenitas (kemajemukan). Harapan dari pendidikan tersebut, jangan ada lagi monopoli kebenaran (truth claim) atas suatu kelompok tertentu.

\section{B. Teori / Konsep}

\section{Pengertian dan Unsur-unsur Pesantren}

Pesantren merupakan lembaga pendidikan Islam tertua di tanah Jawa Indonesia. Selain nuansa keislaman yang identik dan khas, pesantren juga memiliki makna keaslian (indigenous) Indonesia. 7 Pesantren menjadi tempat untuk pembinaan moral atau akhlak dan spiritual kesalehan seseorang serta pengajaran ilmu-ilmu agama Islam yang menjadi ciri dan tata nilai yang khas. Banyak asumsi yang berkembang, bahwa setiap lulusan pesantren mempunyai jiwa ikhlas, jiwa sederhana, jiwa persaudaraan, jiwa mandiri, dan jiwa kebebasan atau kemerdekaan, yang selanjutnya lima hal ini disebut panca jiwa pesantren.

Secara etimologi, istilah pesantren berasal dari kata "santri", yang dengan awalan pe- dan akhiran -an berarti tempat tinggal para santri. Kata "santri" juga merupakan penggabungan antara suku kata sant (manusia baik) dan t ra (suka menolong), sehingga kata pesantren dapat diartikan sebagai tempat mendidik manusia yang baik. ${ }^{8}$ Menurut Abdurahman Wahid, "pondok pesantren mirip dengan akademi militer atau biara (monestory, convent) dalam arti bahwa mereka yang berada di sana mengalami suatu kondisi totalitas". ${ }^{9}$

Sementara, Dhofier menyebutkan bahwa menurut Profesor Johns, istilah "santri" berasal dari bahasa Tamil yang berarti guru mengaji, sedang C C Berg berpendapat bahwa istilah tersebut berasal dari istilah shast $\mathrm{r}$ i yang dalam bahasa India berarti orang yang tahu buku-buku suci Agama Hindu, atau seorang sarjana

\footnotetext{
${ }^{6}$ Ahmad Lucito, “Filsafat Nilai dalam Islam” dalam Chabib Thoha et.al, Reformulasi Filsafat Pendidikan Islam, (Yogyakarta: Pustaka Pelajar dan FT. IAIN Walisongo Semarang, 1996), 21.

${ }^{7}$ Nurcholis Madjid, Bilik-bilik Pesanren: Sebuah Potret Perjalanan, (Jakarta; Paramdina, 1997), 3.

${ }^{8}$ Manfred Ziemek, Pesantren Dalam Perubahan Sosial, terj. Butche B. Soendjojo, cet I. (Jakarta : P3M, 1986), 8.

${ }^{9}$ Abdurahman Wahid, Menggerakkan Tradisi Esai-Esai Pesantren, (Yogyakarta: LKIS, 2001),171.
} 
ahli kitab suci Agama Hindu. Kata shast $\mathrm{r}$ i berasal dari kata shast ra yang berarti buku-buku suci, buku-buku agama atau buku-buku tentang ilmu pengetahuan. ${ }^{10}$ Dengan kata lain, istilah santri mempunyai pengertian seorang murid yang belajar buku-buku suci/ ilmu-ilmu pengetahuan Agama Islam.

Sedangkan menurut Ensiklopedi Islam ${ }^{11}$ bahwa pesantren itu berasal dari bahasa Tamil yang artinya guru mengaji atau dari bahasa India "Shastri" dan kata "Shastra" yang berarti buku-buku suci, buku-buku agama atau ilmu tentang pengetahuan. Lain halnya Menurut Soegarda Poerbawatja, ${ }^{12}$ kata pesantren berasal dari kata santri, dengan mendapat tambahan awalan — pe dan akhiran - an yang menentukan tempat, sehingga kata pesantren dapat diartikan sebagai tempat para santri. Sedangkan Karel A. Steenbrink mengemukakan bahwa istilah pondok berasal dari bahasa Arab - funduq yang berarti pesanggrahan atau penginapan bagi orang yang bepergian. ${ }^{13}$ Secara garis besar dan umum, pesantren merupakan lembaga pendidikan konvensional yang sejak awal berdirinya hingga sekarang telah banyak mengalami perubahan dan memainkan berbagai macam peran di Indonesia. Unsurunsur pesantren yang terdiri dari kyai, santri, masjid, pondok dan kitab kuning adalah elemen unik yang membedakan pesantren dengan lembaga pendidikan lainnya.

Peran penting kyai $^{14}$ dalam pendirian, pertumbuhan, perkembangan dan pengurusan sebuah pesantren berarti dia merupakan unsur yang paling esensial. Sebagai pemimpin pesantren, watak dan keberhasilan pesantren banyak bergantung pada keahlian dan kedalaman ilmu, karismatik dan wibawa, serta ketrampilan kyai. Dalam konteks ini, pribadi kyai sangat menentukan sebab dia adalah tokoh sentral dalam pesantren. ${ }^{15}$

Selanjutnya, hubungan pendidikan Islam dan masjid sangat dekat dan erat dalam tradisi Islam di seluruh dunia. Sejak zaman Rasulullah kaum muslimin telah memanfaatkan masjid untuk tempat beribadah, sekaligus tempat belajar (pendidikan Islam). Sebagai pusat kehidupan rohani, sosial dan politik, dan pendidikan Islam, masjid merupakan aspek kehidupan sehari-hari yang sangat penting bagi masyarakat

${ }^{10}$ Zamakhsyari Dhofier, Tradisi Pesantren: Studi Tentang Pandangan Hidup Kyai, (Jakarta; LP3ES, 1985), 18.

${ }^{11}$ Tim penyusun Kamus Pusat Pembinaan dan Pengembangan Bahasa, Kamus Besar Bahasa Indonesia, cet. 3, (Jakarta; 1990), 99.

${ }^{12}$ Soegarda Poerbawatja, Ensiklopedi Pendidikan, (Jakarta : Gunung Agung, 1976), 279.

${ }^{13}$ Karel A. Steenbrink, Pesantren Madrasah Sekolah, (Jakarta : LP3ES, 1982), 22

${ }^{14}$ Istilah kyai bukan berasal dari bahasa Arab, melainkan dari bahasa Jawa, Zamaksari Dhofier mengatakan; Dalam bahasa Jawa, perkataan kyai dipakai untuk tiga jenis gelar yang berbeda, yaitu: a) Sebagai gelar kehormatan bagi barang-barang yang dianggap keramat; contohnya, "kyai garuda kencana" dipakai untuk sebutkan kereta emas yang

ada di Kraton Yogyakarta; b) Gelar kehormatan bagi orang-orang tua pada umumnya; c) Gelar yang diberikan oleh masyarakat kepada orang ahli agama Islam yang memiliki atau menjadi pimpinan pesantren dan mengajar kitab-kitab Islam klasik kepada para santrinya. Lihat Ibid., Manfred Ziemek, Pesantren Dalam ..., 130.

${ }^{15}$ Hasbullah, Sejarah Pendidikan Islam di Indonesia: Lintasan Sejarah Pertumbuhan dan Perkembangan, (Jakarta; PT. Raja Grafindo Persada, 1999), 44. 
muslim. Dilingkungan pesantren, masjid dianggap sebagai "tempat yang paling tepat untuk mendidik para santri, terutama dalam praktek sembahyang lima waktu, khutbah, dan sembahyang Jumat, dan pengajaran kitab-kitab Islam klasik. ${ }^{16}$ Pada umumnya masjid itu terletak dekat atau di belakang rumah kyai.

Santri merupakan unsur yang penting sekali dalam perkembangan sebuah pesantren, karena langkah pertama dalam tahap-tahap membangun pesantren adalah bahwa harus ada murid yang datang untuk belajar dari seorang alim. Kalau murid itu sudah menetap di rumah seorang alim, baru seorang alim itu bisa disebut kyai dan mulai membangun fasilitas yang lebih lengkap untuk pondoknya.

Unsur pesantren berikutnya adalah santri. Santri biasanya terdiri dari dua kelompok, yaitu santri kalong dan santri mukim. Santri kalong merupakan bagian santri yang tidak menetap dalam pondok tetapi pulang ke rumah masing-masing sesudah selesai mengikuti suatu pelajaran di pesantren. Santri kalong biasanya berasal dari daerah-daerah sekitar pesantren jadi tidak keberatan kalau sering pergi pulang. Makna santri mukim ialah putera atau puteri yang menetap dalam pondok pesantren dan biasanya berasal dari daerah jauh. Pada masa lalu, kesempatan untuk pergi dan menetap di sebuah pesantren yang jauh merupakan suatu keistimewaan untuk santri karena dia harus penuh cita-cita, memiliki keberanian yang cukup dan siap menghadapi sendiri tantangan yang akan dialaminya di pesantren. ${ }^{17}$

Lain halnya dengan pondok, definisi singkat istilah 'pondok' adalah tempat sederhana yang merupakan tempat tinggal kyai bersama para santrinya. ${ }^{18}$ Di Jawa, besarnya pondok tergantung pada jumlah santrinya. Ada pondok yang sangat kecil dengan jumlah santri kurang dari seratus sampai pondok yang memiliki tanah yang luas dengan jumlah santri lebih dari tiga ribu. Tanpa memperhatikan berapa jumlah santri, asrama santri wanita selalu dipisahkan dengan asramasantri laki-laki.

Selain itu, di dalam komplek sebuah pesantren juga terdapat gedung-gedung selain dari asrama santri dan rumah kyai, termasuk perumahan ustad, gedung madrasah, lapangan olahraga, kantin, koperasi, lahan pertanian dan/atau lahan pertenakan. Kadang-kadang bangunan pondok didirikan sendiri oleh kyai dan kadang-kadang oleh penduduk desa yang bekerja sama untuk mengumpulkan dana yang dibutuhkan. Sistem asrama ini merupakanciri khas tradisi pesantren yang membedakan sistem pendidikan pesantren dengan system pendidikan Islam lain seperti sistem pendidikan di daerah Minangkabau yang disebut surau atau sistem yang digunakan di Afghanistan. ${ }^{19}$

Dan unsur yang terakhir adalah kitab-kitab Islam klasik dikarang para ulama terdahulu dan termasuk pelajaran mengenai macam-macam ilmu pengetahuan agam Islam dan Bahasa Arab. Dalam kalangan pesantren, kitab-kitab Islam klasik sering disebut kitab kuning oleh karena warna kertas edisi-edisi kitab kebanyakan berwarna

${ }^{16}$ Ibid., Zamakhsyari Dhofier, Tradisi Pesantren...49.

${ }^{17}$ Ibid., 52

${ }^{18}$ Ibid., Hasbullah, Sejarah Pendidikan Islam ..., 142.

${ }^{19}$ Ibid., Zamakhsyari Dhofier, Tradisi Pesantren..., 45. 
kuning. Menurut Dhofier, "pada masa lalu, pengajaran kitab-kitab Islam klasik, merupakan satu-satunya pengajaran formal yang diberikan dalam lingkungan pesantren." 20

Pada saat ini, kebanyakan pesantren telah mengambil pengajaran pengetahuan umum sebagai suatu bagian yang juga penting dalam pendidikan pesantren, namun pengajaran kitab-kitab Islam klasik masih diberi kepentingan tinggi. Pada umumnya, pelajaran dimulai dengan kitab-kitab yang sederhana, kemudian dilanjutkan dengan kitab-kitab yang lebih mendalam dan tingkatan suatu pesantren bisa diketahui dari jenis kitab-kitab yang diajarkan. Ada 8 (delapan) macam bidang pengetahuan yang diajarkan dalam kitab-kitab Islam klasik, termasuk: nahwu dan saraf (morfologi), fiqh, usul fiqh, hadis, tafsir, tauhid, tasawwuf, etika, dan cabang-cabang lain seperti tarikh dan balaghah. Semua jenis kitab ini dapat digolongkan kedalam kelompok menurut tingkat ajarannya, misalnya: tingkat dasar, menengah dan lanjut. Kitab yang diajarkan di pesantren di Jawa pada umumnya sama. $^{21}$

Dalam perkembangannya, tipologi pesantren terbagi menjadi dua bagian, yaitu pesantren tradisional (Salaf), pesantren modern (Khalaf) dan pesantren komprehensif. ${ }^{22}$ Kategorisasi tentang tipologi pesantren seperti ini bagi sebagian publik cenderung di generalisasi untuk mendikotomikan pesantren dengan kesimpulan bahwa tindakan ekstremisme, terorisme bermula dari pesantren tradisional yang diasosiasikan bersifat fundamentalis. Sedangkan pesantren yang modern dan komprehensif dianggap lebih moderat. Kendati pun demikian, karakter pesantren semacam ini tidak dapat berimplikasi hanya dengan cara pandang dikotomi semata. Oleh karena itu, perlu adanya cara pandang yang lebih holistik dan paradigma komprehensif tentang pesantren ditinjau dari berbagai aspeknya baik dinamika keagamaan, pendidikan, sosial, budaya, ekonomi, maupun politik di dalamnya.

\section{Konsep Inklusif, Intoleransi Radikalisme dan Mitigasi}

Indonesia merupakan negara multikultural terbesar di dunia. Kebenaran dari pernyataan ini dapat dilihat dari kondisi sosio-kultural maupun geografis yang begitu

${ }^{20}$ Ibid., 50 .

${ }^{21}$ Ibid., Hasbullah, Sejarah Pendidikan Islam ..., 50.

${ }^{22}$ Pertama, tipe pesantren tradisional (salaf) sistem pengajaran dan materi yang diampaikan masih serba klasik, bahkan penggunaan produk-produk hasil peradaban modern semacam radio, televisi, handphone, komputer dan lain sebagianya dilarang keras. Kedua, tipe pesantren modern berusaha mengntegrasikan sistem dan materi pengajaran klasikal dan sekolah ke dalam pesantren sebagai proses adaptasi dengan perkembagan dan keniscayaan sejarah yang tidak bisa dibantah dan dilakukan seleksi materi yang diajarkan agar tidak berpotensi merusak ajaran Islam. Dan ketiga, tipe pesantren komprehensif yang berusaha mengintegarsikan sistem pendidikan dan pengajaran yang tradisional dan yang modern dengan bersama-sama mengembangkan sistem pendidikan pesantren dan persekolahan guna pengingkatan kapasitas lembaga pendidikan dan pemberdayaan masyarakat sekitar. Lihat M. Shodiq, Pesantren dan Perubahan Sosial, (UIN Sunan Ampel Surabaya; Jurnal Falasifa, 2011), 110-112. 
beragam dan luas. ${ }^{23}$ Jika mengacu pada PNPS no. 1 tahun 1969 - yang masih dipertahankan Mahkamah Konstitusi-Indonesia memiliki 5 (lima) agama. Di bawah pemerintahan KH. Abdurrahman Wahid (Gus Dur), Konghucu menjadi agama keenam. Meski hanya 6 (enam), di dalam masing-masing agama tersebut terdiri dari berbagai aliran dalam bentuk organisasi sosial. Begitu juga ratusan aliran kepercayaan hidup dan berkembang di Indonesia.

Apabila dapat dikelola secara baik, kemajemukan sejatinya merupakan modal sosial yang amat berharga bagi pembangunan bangsa. Sebaliknya, jika tidak dapat dikelola secara baik, maka kemajemukan berpotensi menimbulkan konflik dan gesekan-gesekan sosial. Sepertinya Indonesia merupakan negara yang belum mampu mengelola kemajemukan dengan baik. Terutama pasca tumbangnya rezim Orde Baru, aksi terorisme dan radikalisme Islam merebak di Indonesia.

Upaya membendung radikalisme, intoleransi beragama perlunya sebuah mitigasi terhadap pemahaman dimaksud. Radikalisme memiliki sejarah yang dimunculkan dengan sikap fanatik, intoleransi, dan ekslusif dalam Islam pertama yang ditampakkan oleh kaum Khawarij sejak abad pertama hijriyah (Santosa, 2012). Kata "radikal" ataupun "radikalisasi" dalam frasa "paham radikal" dan "radikalisasi agama" dalam berita-berita di media bisa diartikan sebagai sesuatu yang berlebihan, fanatik, dan tentunya tidak baik. Radikalisme sendiri memiliki ciri yang melekat yaitu sebagai berikut: Pertama, Memperjuangkan Islam secara Kaffah, dimana syariat Islam sebagai hukuman negara. Kedua, mendasarkan praktek keagamaannya pada orientasi masa lalu (safety). Ketiga, cenderung memusuhi Barat, terutama sekularisasi dan modernisasi. Keempat, perlawanan terhadap liberalisme islam yang tengah berkembang di Indonesia. (Abdurrahmad Mas'ud, 2014).

Sedangkan kata intoleransi berasal dari prefik in-yang memiliki arti "tidak, bukan" dan kata dasar toleransi yang memiliki arti sifat atau sikap toleran, batas ukur untuk penambahan atau pengurangan yang masih diperbolehkan penyimpangan yang masih dapat diterima dalam pengukuran kerja. Dalam hal ini, pengertian toleransi yang dimaksud adalah "sifat atau sikap toleran". Kata toleran sendiri didefinisikan sebagai "bersifat atau bersikap menenggang (menghargai, membiarkan, membolehkan) pendirian (pendapat, pandangan, kepercayaan, kebiasaan, kelakuan, dan sebagainya) yang berbeda atau bertentangan dengan pendirian sendiri." Kata intoleransi berasal dari prefikin yang memiliki arti "tidak, bukan" dan kata dasar toleransi yang memiliki arti sifat atau sikap toleran, batas ukur untuk penambahan atau pengurangan yang masih diperbolehkan penyimpangan yang masih dapat diterima dalam pengukuran kerja. Dalam hal ini, pengertian toleransi yang dimaksud adalah "sifat atau sikap toleran". Kata toleran sendiri didefinisikan sebagai "bersifat atau bersikap menenggang (menghargai, membiarkan, membolehkan) pendirian

23 M. Ainul Yaqin, Pendidikan Multikultural; Corss-Cultural Understanding Untuk Demokras dan Keadilani, (Yogyakarta: Pilar Media, 2005), 4. 
(pendapat, pandangan, kepercayaan, kebiasaan, kelakuan, dan sebagainya) yang berbeda atau bertentangan dengan pendirian sendiri."

Kata intoleransi berasal dari prefik in- yang memiliki arti "tidak, bukan" dan kata dasar toleransi yang memiliki arti sifat atau sikap toleran, batas ukur untuk penambahan atau pengurangan yang masih diperbolehkan penyimpangan yang masih dapat diterima dalam pengukuran kerja. Dalam hal ini, pengertian toleransi yang dimaksud adalah "sifat atau sikap toleran". Kata toleran sendiri didefinisikan sebagai "bersifat atau bersikap menenggang (menghargai, membiarkan, membolehkan) pendirian (pendapat, pandangan, kepercayaan, kebiasaan, kelakuan, dan sebagainya) yang berbeda atau bertentangan dengan pendirian sendiri”. Intoleransi beragama adalah suatu kondisi jika suatu kelompok (misalnya masyarakat, kelompok agama, atau kelompok non-agama) secara spesifik menolak untuk menoleransi praktikpraktik, para penganut, atau kepercayaan yang berlandaskan agama.

Mitigasi adalah tindakan-tindakan untuk mengurangi atau meminimalkan dampak dari suatu bencana terhadap masyarakat. Mitigasi di sebagai upaya yang ditujukan untuk mengurangi dampak dari bencana, Mitigasi adalah serangkaian upaya untuk mengurangi risiko bencana, baik melalui pembangunan fisik maupun penyadaran dan peningkatan kemampuan menghadapi ancaman bencana. (UU No 24 Tahun 2007, Bab I Ketentuan Umum, Pasal 1 angka 9) (PP No 21 Tahun 2008, Bab I Ketentuan Umum, Pasal 1 angka 6).

Beberapa waktu ke belakang, ekstrimisme di ruang publik silih berganti mengguncang negeri ini. Sebut saja misalnya bom Bali I, bom Bali II, bom Kedutaan Besar Australia, bom Hotel JW Marriot I, bom Hotel JW Marriot II, bom Hotel Ritz Carlton, - bom bukull, bom panci yang ditujukan ke sejumlah tokoh, _-bom Jum'at di masjid Mapolres Cirebon dan Medan serta bom bunuh diri di Gereja Bethel Injil Sepenuh (GBIS) Kepunton, Solo dan masih banyak lagi tindakan ekstremisme lainnya.

Selain sederet kasus terorisme seperti disebutkan di atas, radikalisme berlebelkan Islam juga merebak di mana-mana. Contoh kasus radikalisme Islam yang terjadi di Indonesia adalah penyerangan terhadap Jemaat Ahmadiyah di Cikeusik, Pandeglang, Banten serta penyerangan pondok pesantren yang diduga beraliran Syiah di Pasuruan dan Sampang, Jawa Timur, Kasus pengrusakan patung dan ucapan sampurasun di Purwakarta. Banyaknya konflik yang terjadi di Indonesia menunjukkan bahwa bangsa ini belum memahami arti keragaman dan perbedaan. Tidak sedikit di antara manusia yang hendak meniadakan kebhinekaan (plurality) dan menggantinya dengan ketunggalan dan keseragaman (uniformity). Ironisnya, para teroris dan kaum radikalis mengklaim bahwa semua itu dilakukan karena perintah agama (Islam).

Maraknya aksi radikalisme dan terorisme atas nama Islam tersebut sedikit banyak telah menempatkan umat Islam sebagai pihak yang dipersalahkan. Ajaran jihad dalam Islam seringkali dijadikan sasaran tuduhan sebagai sumber utama 
terjadinya kekerasan atas nama agama oleh umat Islam. Lembaga pendidikan Islam di Indonesia semisal pondok pesantren, juga tidak lepas dari tuduhan yang memojokkan tersebut. Lembaga pendidikan Islam tertua dalam sejarah Indonesia ini seringkali diasosiasikan sebagai "markas atau sentral pemahaman Islam yang sangat fundamental" yang kemudian menjadi akar bagi gerakan radikal mengatasnamakan Islam.

Oleh sebab itu, perlu dibangun kembali persepsi yang baik tentang makna "ijtihad" dunia pesantren yang sesungguhnya telah memperjuangkan nilai-nilai inklusif dalam proses transformasi pendidikan pesantren.

Inklusif adalah sikap berfikir terbuka dan merhargai perbedaan, baik perbedaan tersebut dalam bentuk pendapat, pemikiran, etnis, tradisi-berbudaya hingga perbeda-an agama. ${ }^{24}$ Sikap terbuka kemudian menjadi prasyarat utama terjadinya dialog antar agama, tradisi atau dialog antar peradaban dengan tujuan agar tidak lagi ada pembenaran absolut dan ekstrem dalam berpendapat ataupun beragama, namun bukan hal ini yang dimaksud oleh penulis sebagai paradigma inklusif, melainkan sebuah tujuan untuk menemukan kebenaran universal dalam setiap perbedaan atau sekedar tidak saling mencurigai.

Dalam tataran teologi, inklusif ini merupakan lawan dari eksklusif. Masalah inklusif dan eksklusif dalam Islam merupakan kelanjutan dari pemikiran/ gagasan neo-modernisme kepada wilayah yang lebih spesifik setelah pluralisme, tepatnya pada bidang teologi. ${ }^{25}$ Gagasan tersebut berangkat, bahwa teologi kita pada saat ini seperti sudah di desain dalam kerangka teologi eksklusif yang menganggap bahwa kebenaran dan keselamatan (truth and salvation) suatu agama, menjadi monopoli agama tertentu. Sementara agama lain, diberlakukan bahkan ditetapkan standar lain yang sama sekali berbeda bahkan salah dan karenanya tersesat ditengah jalan.

Oleh karenanya hal ini sudah masuk ke wilayah state of mind kita. Cara pandang suatu komunitas agama (religious community) terhadap agama lain, dengan menggunakan cara pandang agamanya sendiri. Teologi Eksklusif tanpa menyisakan ruang toleransi untuk berempati, apalagi simpati, bagaimana orang lain memandang agamanya sendiri.

Seperti sudah taken for granted kita seringkali menilai dan bahkan menghakimi agama orang lain, dengan memakai standar teologi agama kita sendiri. Pun sebaliknya, orang lain menilai bahkan menghakimi kita, dengan memakai standar teolog agamanya sendiri. Jelas ini suatu mission imposible untuk bisa saling bertemu, apalagi sekedar toleran. Hasilnya justru perbandingan terbaliknya: masingmasing agama malah menyodorkan proposal — klaim kebenaran (claim of truth) dan — klaim keselamatan (claim of salvation) yang hanya — ada dan — berada pada agamanya sendiri-sendiri, sementara pada agama lain dituduh salah, menyimpang, bahkan menyesatkan.

${ }^{24} \mathrm{Ibid}, 34$.

${ }^{25}$ Nurcholish Madjid, Islam Kemodernan dan Keindonesiaan, (Jakarta: Mizan, 1987), 70. 
Dalam Islam, paradigma teologi inklusif nampak terlihat dari kata al-Islam itu sendiri. Menurut Cak Nur, ${ }^{26}$ kata al-Islam tidak selalu harus dimaknai sebagai organized religion atau agama yang telah terlembaga. Ia bisa diartikan secara lebih umum, yaitu setiap agama yang mengajarkan sikap pasrah kepada Tuhan, sebagaimana arti kata Islam itu sendiri.

Sikap yang demikian adalah merupakan inti ajaran dari agama-agama Ibrahim Yahudi, Kristen dan Islam). Dalam hal ini, Cak Nur mengutip Q.S. AlAnkabut (29) ayat 46. Menurut Cak Nur, ${ }^{27}$ kata al-muslimun pada ayat tersebut harus diartikan sesuai makna generiknya, yaitu orang-orang yang pasrah kepada Tuhan. Dengan demikian para penganut kitab suci pada dasarnya termasuk dalam kategori al-muslimun, selama mereka memiliki sikap pasrah kepada Tuhan. Cak Nur juga menegaskan bahwa Tuhan tidak akan menerima seorang muslim (dalam pengertian organized religion), bila dalam beragama tidak dibarengi sikap pasrah kepada Tuhan.

Sikap tersebut, juga mengacu pada Q.S. Ali Imran (3) ayat 19. Hukum ketundukan dan kepasrahan semacam ini menurut Cak Nur harus dijalani oleh setiap manusia, kapan dan di manapun. Sebab, ia merupakan perjanjian primordial antara manusia dengan Tuhannya sejak manusia diciptakan. Cara pandang yang seperti ini nampaknya dipengaruhi oleh penafsiran Abdullah Yusuf Ali $^{28}$ yang mengatakan bahwa Islam bukanlah agama sekte atau etnis. Semua agama adalah satu, karena kebenaran itu satu adanya. Penafsiran semacam ini muncul sebagai bentuk kesadaran akan segi kontinuitas beragama. Oleh karenanya, kaum muslimin harus berpegang pada prinsip kontinuitas tersebut dengan beriman kepada semua nabi dan rasul tanpa membeda-bedakannya.

Selain itu, landasan teologis untuk bersikap inklusif ini juga terdapat pada Surat Al-Baqarah: 62, bahwa:

"Sesungguhnya orang-orang Mukmin, orang-orang Yahudi, dan orangorang Nasrani dan orang-orang shabiin, siapa saja di antara mereka beriman kepada Allah, hari kemudian, dan beramal shaleh, mereka akan menerima pahala dari Tuhan, tidak ada kekhawatiran terhadap mereka, dan tidak pula mereka bersedih hati."

\section{Metode Penelitian}

Berkaitan dengan jenis penelitian, penelitian dilaksanakan di dasarkan pada studi analisis lapangan yang kemudian dilanjutkan dengan studi perpustakaan dari beberapa argumen ilmuwan serta informasi dari beberapa sumber pustaka terkait. Adapun dalam pelaksaanannya, penelitian ini dilakukan di pondok pesantren Al-Asy'ariyah Wanayasa dan Nurul Jadid Bojong sebagai sampel objeknya yang meliputi kyai, santri dan masyarakat sekitar.

\footnotetext{
${ }^{26}$ Nurcholish Madjid, Islam Agama Kemanusiaan, (Jakarta: Paramadina, 2003), x-xviii

${ }^{27}$ Ibid., X-Xviii

${ }^{28}$ Abdullah Yusuf Ali, Qur"an dan Tafsirnya, terj. Ali Audah, (Jakarta: Pustaka Firdaus, 1993), 145.
} 
Berdasarkan hal itu, dalam upaya untuk menganalisis permasalahan data tersebut dilakukan dengan 3 (tiga) cara. Pertama, content analysis atau analisis isi, yaitu bahwa analisis wacana merupakan usaha memahami makna tuturan dalam konteks, teks dan situasi. ${ }^{29}$ Kedua, analisis logika reflektif yaitu analisis data yang berpedoman pada cara berfikir reflektif, cara berfikir dalam proses mondar-mandir secara cepat antara induksi dan deduksi atau triangulasi. Dan Ketiga, analisis komparasi yaitu metode untuk membandingkan beberapa segi yang meliputi data, situasi dan konsepsi filosofis. ${ }^{30}$

\section{Mitigasi Intoleransi dan Radikalisme Melalui Pembelajaran Inklusif di Pondok Pesantren}

\section{Pendidikan Pesantren Inklusif}

Pada awal berdirinya, pesantren lebih dikenal sebagai lembaga pendidikan Islam, yang bertujuan untuk menyebarkan agama dan memperdalam agama Islam. Adanya gerakan bagi penyebaran agama, gerakan bagi pemahaman kehidupan, dan gerakan-gerakan sosial terpadu dalam seluruh aktifitas pesantren. Pesantren tidak hanya memiliki kemampuan untuk pembinaan pribadi muslim, namun juga usaha mengadakan perubahan dan perbaikan sosial kemasyarakatan. Pesantren mampu memiliki juga pengaruh yang besar baik terhadap santri dan alumninya, melainkan juga masyarakat sekitar pesantren. Pada masa awal-awal berdiri dan berkembangnya pesantren, fungsi sosial pesantren lebih terasa dibandingkan dengan fungsi pesantren sebagai lembaga pendidikan. Sekilas sebagai contoh, dapat dilihat bagaimana kiprah pesantren pada masa Wali Songo, masa kerajaan Islam Jawa, masa melawan penjajah, dan masa-masa revolusi kemerdekaan. ${ }^{31}$

Dalam pandangan KH. Abdurrahman Wahid (Gus Dur) menjelaskan bahwa pesantren merupakan sebuah kultur dengan pola kehidupan yang unik, ia mampu bertahan selama berabad-abad dalam mempergunakan nilai-nilai hidupnya sendiri. ${ }^{32}$ Oleh karena itu, dalam jangka panjang, pesantren berada dalam kedudukan kultural yang relatif lebih kuat dari pada masyarakat di sekitarnya. Kedudukan ini dapat dilihat dari kemampuan pesantren melakukan transformasi total sikap hidup masyarakat sekitarnya, tanpa ia sendiri harus mengorbankan identitasnya. ${ }^{33}$ Dengan pesan yang sangat penting tersebut, dapat dijadikan pijakan untuk menjadikan pesantren sebagai agen perubahan (agent of change), (Muhamad Ridwan Effendi,

29 Alex Sobur, Analisis Teks Media: Suatu Pengantar untuk Analisis Wacana,Analisis Semiotik dan Analisis Framing, (Bandung: PT. Remaja Rosdakarya, 2004), 49.

30 Anton Bekker, Achmad Charis Zubair, Metodologi Penelitian Filsafat, (Yogjakarta: Kanisius, 1990), 111-112.

${ }^{31}$ HM. Nurdin Syafi'i, "Kontribusi Pesantren dalam Mencetak Generasi Mandiri”, Tesis, (Yogyakarta: Pascasarjana UIN Sunan Kalijaga, 2008), 47-48.

${ }^{32}$ Azyumardi Azra, Pendidikan Islam: Tradisi dan Modernisasi Menuju Milenium Baru, (Jakarta: Logos Wacana Ilmu, 1999), 95

33 Abdurrahman Wahid, "Pesantren sebagai Kultur”, dalam Dawam Raharjo (ed.), Pesantren dan Pembaharuan, (Jakarta: LP3ES, 1995), 43 
Rudi M. Barnansyah, 2019)terhadap masyarakat sekitarnya. Pesantren diharapkan dapat menjadi dinamisator dan katalisator pembangunan masyarakat. ${ }^{34}$

Secara perlahan, pesantren sebagai agen perubahan sosial terlaksana pada perubahan sistem pengorganisasian pengajaran, dan sejalan dengan itu, pengetahuan umum diajarkan secara resmi, menguak doktrin tradisi masa lampau yang seakan mengharapkan hal tersebut dilakukan. Perubahan ini terjadi tanpa memudarnya semangat dan hakikat pesantren sehingga tidak merubah dan mempengaruhi identitas kultural pesantren. Secara sosiologis, perubahan ini didasari oleh tuntutan perubahan sosial yang mengalir deras di masyarakat dan secara perlahan-lahan berimabas pada pesantren. Pesantren yang lahir dari dan di tengah-tengah masyarakat terus tumbuh dan berkembang, mendesak nilai dan norma agama untuk difahami. Sehingga, eksistensi pesantren mengaca pada proses perubahan yang terjadi di masyarakat. Sebagai lembaga pendidikan agama dan lembga sosial yang tumbuh dan berkembang dari masyarakat, maka proses sosial yang saling berkelindan antara pesantren dan masyarakat ini tidak dapat dihindarkan lagi. ${ }^{6}$

Pesantren dengan kurikulum yang diajarkan di dalamnya, bukan hanya merupakan pusat kehidupan rohani dan berpandangan hidup pada orientasi masalah akhirat dan ibadah kepada Tuhan saja. Namun pada dasarnya materi-materi agama yang terrepresentasikan oleh fikih, tauhid dan lainnya telah banyak menggambarkan tentang urusan sosial masyarakat, persoalan-persoalan dunia, yang diwujudkan dalam kehidupan sehari-hari. Jadi, keilmuan agama yang selama ini terkesan hanya berorientasi uhkrowi, pada dasarnya telah mempresentasikan urusan duniawi, namun masih belum dikenal dalam metode pendidikan modern. ${ }^{7}$

Pembaharuan yang terjadi pada pesantren, dapat diamati dari awal dirintisnya pesantren yang hanya merupakan masjid/surau kecil pusat ibadah dan dakwah, berubah menjadi sebuah lembaga pendidikan yang lebih luas perannya. Bahkan pesantren diakui telah mampu ikut serta dalam perubahan masyarakat sekitarnya. Banyak contoh yang bisa diungkapkan bahwa masyarakat yang dulunya menjadi pusat kemaksiatan, kriminalitas dan berbagai bentuk tidak kejahatan setelah di situ berdiri pesantren maka berubah menjadi masyarakat yang baik dan sejahtera. Sehingga, pesantren berkembang dari pengalaman sosiologis lingkungannya, dan mampu menyesuaikan dirinya dengan perkembangan masyarakatnya.

Lebih lanjut, KH. Abdurrahman Wahid (Gus Dur) mengatakan bahwa model tradisi keilmuan di pesantren dari masa ke masa mengalami perubahan yang sangat signifikan yang juga dibarengi dengan penampilan manifestasi keilmuannya yang berubah-ubah pula dari waktu ke waktu. Walau demikian menurutnya masih dapat ditelusuri beberapa hal inti yang masih tetap merupakan merupakan tradisi keilmuan pesantren sejak datangnya Islam ke Indonesia hingga saat ini.

${ }^{34}$ Hermansyah Putra, "Pondok Pesantren dan Tantangan Globalisasi”, Tesis, (Yogyakarta: Pascasarjana UIN Sunan Kalijaga, 2010), 46 
Secara tegas Gus Dur mengatakan kesemua itu menunju ke sebuah asal usul yang bersifat historis sekaligus sosiologis yang menjadi faktor utama dalam mendorong perubahan dan perkembangan pesantren itu sendiri.

Periode Pertama, tradisi keilmuan di pesantren lebih banyak terpengaruh oleh tradisi Hellenisme yang bermula dari proses penjarahan daerah-daerah timur tengah oleh Iskandar Agung dari Makedonia beberapa abad sebelum Masehi. Helenisme ini menurut Gus Dur telah berkembang dengan menyebarkan silsafat Yunani ke seantero kawasan timur tengah sekaligus meninggalkan pembawaan mistik Dyonisis di Yunani kuno bercampur dengan semenanjung Asia kecil (Asia Minor) hingga akhirnya dapat membentuk apa yang dikenal dalam agama Kristen sebagai sekte-sekte bidat, seperti sekte Nestoria.

Gus Dur menguraikan secara epistemic, histori dan asal-usul keilmua dipesantren yang bermula dari anjuran al-qur'an dan hadis untuk mengembangkan ilmu pengetahuan hingga akhirnya menjadi dasar hukum bagi sebagian sahabat untuk mengembangkan perangkat keilmuannya sendiri.(Manpan Drajat, 2015) Hal ini dapat dibuktikan dengan kelompok-kelompok yang telah melakukan spesialisasi keilmuan sejak masa dini dari sejarah perjalanannya yang cukup panja/ng. berikut ini kutipannya:

"Asal usul tradisi keilmuan dipesantren dapat dilihat pada perkembangan ilmu-ilmu ke Islaman sejak ada dalam masyarakat Islam yang pertama. Salah satu watak utama dari Islam adalah tekanan yang berat sekali pada aspek pendidikan, sebagaimana dapat dilihat pada sejumlah sumber motivatif, seperti ayat-ayat al-qur'an dan hadits nabi yang menggambarkan pentingnya arti sebuah ilmu bagi Islam dalam pandangan Allah dan dalam pandangan Nabi Muhammad SAW".

Pada fase ini menurut Gus Dur para ulama' mulai berani mengambil beberapa keilmuan dari luar untuk dipahami dan diserap sebagai perangkat dasar dan tolak ukur untuk mengartikulasikan al-Quran dan hadis secara harfi. ${ }^{35}$ Kombinasi dari sikap humanisme seperti itu dan kecenderungan normatif untuk memperlakukan alqur'an dan hadits sebagai sumber formal, dengan sendirinya dapat membentuk sistem tradisi keilmuan baru yang unik. ${ }^{36}$ Inilah yang menurut Gus Dur merupakan akar utama sumber keilmuan dipesantren.

\footnotetext{
${ }^{35}$ Metode harfi secara etimologi bermakna - jalan kesumber airll. Yaitu sebuah metode berfikir secara radikal untuk mengaitkan seluruh persolan dengan sumber utama keilmuan islam yaitu al-qur'an dan hadits. Metode ini menurut Antony Black adalah model pemikiran interpretasi atas al-qur'an dan hadits dengan pendekan kosakata yang menjadi teknis utamannya sehingga menghasilkan kesimpulan yurispundensif (Hukum syar "i) seperti yang dilakukan oleh syafi'I sebagai contoh proses intelektualitas islam yang berhasil ketika mensintesiskan antara madzhab hokum literis di Madina tempat ia wafat dan madzhabnya Abu Hanifah. Black juga manmbahkan bahwa metede ini merupakan corak pandangang utama kelompok sunni terutama digunakan untuk menetapkan hukum syari'at. Lihat Antony Black, Pemikiran Politik Islam dari masa Nabi hingga masa kini, (Jakarta: PT. Serambi Ilmu Semesta, 2000), 97.

${ }^{36}$ Unik menurut Gus Dur karena disatu pihak mereka merupakan sarjana (scholar) yang mempunyai reputasi ilmu yang hebat, tetapi dari segi yang lain mereka tetap merupakan manusia-manusia yang tetap beribadah kepada Allah dan tidak luntur imannya ditengah proses penyerapan yang begitu asif akan
} 
Namun demikian Gus Dur mengakui semua itu menjadi kendur, ketika kendala normatif akhirnya menjadi terlalu besar fungsinya dan system penyerapan fungsinya-pun mulai meredup dikalahkan oleh pengawasan dari dalam. Dan mengatakan "Akhirnya yang ada hanyalah ilmu-ilmu yang sangat normative yang tidak memberikan tempat dan perhatian pada kebutuhan penciptaan rasionalitas ilmiah yang tersendiri dan independent."

Kedua tradisi keilmuan dipesantren yang bersifat fiqih sufistik yang dalam hal ini menurut Gus Dur terbentuk dan bersumber pada gelombang pertama pengetahuan keislaman yang datang kekawasan Nusantara dalam masa anad ke 13 Masehi, ketika bersamaan dengan masuknya Islam kekawasan ini.

Dikatakan bersifat fiqih sufistik, menurut Gus Dur dikarenakan corak dan karakter islam yang pertama kali masuk keindonenesia pertama kali lebih menekankan konsep pen-tauhidan dan pengamalan ilmu-ilmu syariah secara sufisme, hal ini disinyalir selain dikarenakan tidak bisa lepasnya dari proses penyebaran Islam kenegara ini melalui Persia dan anak benua India yang dalam beragama lebih menekankan pada oreintasi tasawuf. Hal ini juga lebih dikarenakan adanya kesmaan (indigenous) antara pemikiran sufisme para penyebar Islam kenusantara dengan watak mistik masyarakat Indonesia pra Islam (dinamismeanimisme).

Hal ini bisa dapat kita lihat dari beberapa literatur pesantren yang lebih banyak menggunakan buku-buku tasawuf dengan menggabungkan fiqih serta amalan-amalan akhlaq dijadikan sebagai bahan pelajaran utama, diantaranya menurut Gus Dur kitab Nidayat al-Hidayah dari Imam al-Ghazali yang merupakan karya fiqh-sufistik paling menonjol dalam berabad-abad bahkan hingga saat ini.

Walaupun pada kenyataanya, dalam perjalanan sejarahnya yang panjang sejak abad ke-13, yaitu selama 7 abad ia berkembang dipesantren manifestasi keilmuan semacam ini bertumpang-tindih dengan pandangan-pandang dan perilaku mistik orang jawa atau penduduk setempa, menurut Gus Dur seperti faham wahdaniyah atau wahdatul wujud (Abdurrahman Singkel), terjadinya perdebatan antara ar-Raniry dan gurunya hingga menghasilkan "pemurnian" ajaran tasawuf di Aceh pada abad ke -16 ini menunjukkan dengan jelas bahwa manifestasi fiqih-sufistik keseluruhan kehidupan ilmiah orang Islam.

Bahkan menurut Gus Dur didalam manifestasi kehidupan kelompokkelompok pembaharuan sekalipun -seperti gerakan Muhammadiyah-, pengaruh tasawuf dalam bentuk akhlaq atau akhlaq sufi begitu kuat. Seperti dibuktikan oleh

peradaban-peradaban lain. Dari sini melahirkan nama-nama besar dalam kamus pesantren al-Khalil ibn Ahmad al-Farahidi (penulis kamus arab pertama: Mu"jam al-,,Ain) yang mampu melahirkan imam Sibawaih rujukan ilmu bahasa pesantren, Ibnu Qutaibah al-Dinawari (pengarang kitab ta"wil muskil alqur"an, tafsir gharib al-qur"an dan juga mengkaji beberapa hadis kontraversi: Ta"wil Mukhtalaf alHadis, yang menurut Gus Dur Ulama' ini sering dibaca salah dengan sebutan —Dainurill hingga menjadi nama kebanyak orang Indonesia -Zainurill dan lain sebagainya. Lihat, Abdurrahman Wahid, Menggerakkan Tradisi Pesantren, Jogyakarta: LKIS, 2001), 26. 
seorang antropolog Jepang Mitsuo Nakamura (1976) yang mengalami kesulitan dalam membedakan penanut sufi bertarekat dan warga pembaharu yang berkhlaq sufi tanpa mengikuti slah satu tarekat.

Selain itu terdapat pula buku yang mementingkan pendalaman akhlaq dalam bentuk pengamalannya secara tuntas dan pendalaman pemahaman secara sufistik kepada ranah kehidupan yaitu syarh al-Hikam karya Ibn Atha'illah al-askandary. ${ }^{37}$

Ketiga akar tradisi keilmuan dipesantren yang bersumber pada pengiriman anak-anak muda dari kawasan Nusantara untuk belajar di Timur Tengah dan akhirnya mereka menghasilkan korp ulama yang tangguh yang mendalamai ilmu agama di Semenanjung Arabiyah, terutama di Makkah. Dari sini lahirlah ulama'ulama' besar seperti kiyai Nawawi Banten, Kiai Mahfudz Termas, Kia Abdul Ghani Bima, Kiai Arsyad Banjar, Kiai Abdus Shamad Palembang, Kiai Hasyim As‘ary Jombang, Kiai Kholil Bangkalan, dan beberapa deretan ulama' lain yang sampai sekrang tidak putus karena kebanyak diantara mereka selain yang menetap di timur tengah -mereka yang kembali ke Tanah Air- kemudian mendirikan pondok pesantren.

\section{Tujuan Pembelajaran Inkklusif di Pesantren}

Dalam hal ini, disebut dengan pesantren inklusif paling tidak dapat dilihat dari beberapa aspek: (1) pesantren tersebut telah menjadi pusat kajian agama-agama; (2) kurikulum pesantren (baik yang word curriculum ataupun hidden curriculum) telah memberi porsi dan perhatian besar dalam pengembangan hubungan antar agama; (3) sang kiai telah akrab dengan agama-agama lain sekaligus para tokohnya; (4) terdapat santri dari luar agama yang telah belajar di dalam pesantren, walaupun mungkin hanya live in di pesantren; (5) banyak tamu dari berbagai agama lain yang sering berkunjung ke pesantren; (6) sivitas pesantren telah familiar dan memahami dengan baik istilah-istilah terkait hubungan antar agama seperti pluralisme, inklusivisme, toleransi dan lain sebagainya; (7) karakter santri dan pesantren yang telah sering berdialog dan bergaul dengan non-muslim, dengan arti kata memunculkan prilaku yang menunjukkan toleransi beragama; dan (8) munculnya karya-karya yang bersinggungan dengan toleransi dan hubungan antar umat beragama.

\footnotetext{
37 Yang salah satu _peniggalan" al-hikam adalah kata "nahdhah" yang kemudian diartikan dengan kebangunan dengan kalimat "la tashab man la yunhidhuka ila „, Allah haluh, wa la yadulluka ila Allah maqaluh, artinya "janganlah kamu bersahabat dengan orang yang dalam hal ihwalnya tidak membangkitkan kamu kepada tuhan, dan janganlah kamu berteman dengan orang yang ucapanucapannya tidak menunjukkan kamu kepada Allah“ maksud Gus Dur mengemukakan hal ini, dengan tanpa sadar kata "Nahdah" kemudian menjadi kata dalam sebuah organisasi besar para Ulama" dikemudian hari yaitu Nahdhatul Ulama“ (NU) sekali lagi ini menunjukkan bukti betapa kuatnya akar tradisi fiqh-sufistik dalam menjadi pandangan dan dasar keilmuan di pesantren Lihat Ibid, Abdurrahman Wahid, Menggerakkan ..., 26.
} 
Yang penting untuk dilakukan adalah adanya pembudayaan toleransi tersebut pada dataran keseharian pesantren. Pesantren berupaya secara intensif dari berbagai agenda dan kegiatan yang kontinu. Sebagai contoh misalnya santri dikenalkan dengan tempat ibadah dan ritual keagamaan agama lain, santri sering diajak dialog atau minimal bergaul dengan "santri" agama lain, bahkan mungkin bagi santri senior bisa diajak mengkaji "doktrin-doktrin" agama lain tersebut setelah mereka menguasi dengan baik doktrin agama Islam. Dengan pembudayaan seperti itu sangat memungkinkan tertanamnya jiwa toleran pada diri santri, sehingga nantinya akan berkembang pada dataran sikap dalam kehidupan di mana pun mereka berada.

Dengan adanya penanaman sikap inklusif secara integral, baik pada pindidikan formal, in-formal dan non-formal khususnya di pesantren, maka setidaknya akan dapat memberikan "keberkahan sosial" sebagai berikut: pertama, untuk keluarga. Dalam dataran keluarga, inklusif merupakan sebuah wacana dan pemikiran yang penting untuk dimengerti dan dipahami bersama anggota keluarga. Bagi kedua orang tua, sudah semestinya memulai dalam pendidikan inklusif ini kepada putra-putrinya sedini mungkin. Pada mulanya anak bisa dikenalkan dengan berbagai wujud keragaman agama yang ada di negeri ini. Namun hal ini tentunya dibarengi pula dengan penanaman keimanan dan tauhid yang kuat secara kontinue. Keberlangsungan dan keseriusan pendidikan ini akan semakin dirasakan manfaatnya manakala sang anak nantinya sudah bisa menalar sendiri dengan baik hal-hal yang ada dihadapannya. Ketika dulu masih kecil ia sering diajari dan difamiliarkan dengan keberagaman, maka dewasa kelak ia akan memiliki paradigma dan mindset yang baik. Baik di sini maksudnya yaitu pemikiran yang mampu menempatkan dirinya pada sebuah kenyataan lingkungan sekitar yang penuh dengan aneka macam keyakinan atau agama yang ia sendiri musti bisa hidup dengan mereka secara normal, positif dan damai.

Kontonuitas pemahaman dan penanaman yang baik, akan banyak mengurangi shock-culture (keterkejutan budaya termasuk di dalamnya keyakinan dan pemahaman) dalam dunia yang mungkin dirasa baru dan asing. Seseorang yang dari awal belum pernah dibiasakan dengan perbedaan dan keragaman, sangat dimungkinkan nantinya akan kurang bisa memahami eksistensi dan ruang gerak orang lain yang berbeda dengannya. Sehingga ia akan termasuk jiwa-jiwa yang ekslusif dan fundamentalis bahkan bisa radikalis. Watak dan krakter ini sangatlah merusak sinergisme manusia sebagai hamba Tuhan sekaligus manusia sebagai makhluk sosial.

Kedua, untuk pesantren. Dengan terbentuknya lingkungan pesantren yang inklusif dan toleran, maka nantinya sangat tidak mungkin pesantren akan menjadi lembaga pendidikan percontohan guna mengembangkan kehidupan beragama yang harmonis di tanah air. Selama ini banyak tudingan miring oleh beberapa kalangan masyarakat, bahkan dari luar negeri, bahwa pesantren merupakan agen yang memproduk para teroris. Pendidikan pesantren telah menanamkaan doktrin-doktrin 
agama yang intoleran kepada santrinya, sehingga mereka memiliki karakteristik yang radikal. Dengan adanya pengembangan toleransi dalam kehidupan bergama ini, image negatif pesantren seperti itu akan sendirinya luntur dan hilang, bahkan sebaliknya pesantren menjadi pusat pengembangan pendidikan toleransi bergama.

Ketiga, untuk masyarakat luas. Setelah terbentuknya sosok manusia yang inklusif dan toleran, maka ia akan mampu membaur bahkan membawa lingkungan sekitarnya menjadi masyarakat yang inklusif dan toleran pula. Minimal ia kan menjadi bahan inspirasi orang lain dalam mengarungi kehidupan yang penuh keragaman ini. Setelah nantinya terbentuk sebuah masyarakat yang seperti itu, maka dalam sekoup yang lebih luas, akan membawa pada situasi dan kondisi wilayah yang kondusif untuk menjalankan rutinitas amaliyah agama masing-masing, tanpa adanya rasa hawatir dan was-was akan adanya intimidasi dan eksploitasi dari orang lain, yang mungkin lebih superior dan berkuasa pada saat itu. Ketika dalam bermasyarakat dan apalagi beragama sudah dimulai dengan adanya rasa was-was dan hawatir seperti kondisi di atas, maka siapapun orangnya, dari agama apapun ia, pada akhirnya tidak akan merasa nyaman dan aman dalam bermasyarakat dan beragama.

Dari sinilah sebenarnya rasa aman dan nyaman merupakan hak terpenting setiap manusia dalam menapaki kehidupannya masing-masing. Hak ini seharusnya bisa diwujudkan oleh masing-masing individu, dengan tetap menjaga dan menghormati hak orang lain, diimbangi dengan melaksanakan kewajibannya masing-masing. Dari sinilah nantinya akan terwujud masyarakat yang berbudaya tinggi atau terwujudnya masyarakat madani, sebagai dambaan seluruh manusia khususnya umat Islam.

Hal inipun juga bersinggungan dengan sebuah sistem negara dan pemerintahan di negeri ini. Seseorang akan cenderung menyatakan bahwa Indonesia sudah merupakan konsep dan sistem yang tepat untuk berkembangnya Islam. Secara keseluruhan, dapat dikatakan Pancasila merupakan perjanjian luhur dari bangsa Indonesia, yang dibuat para pendiri Republik Indonesia menjelang proklamasi kemerdekaan. Sila "Ketuhanan Yang Maha Esa" sendiri merupakan konsensus semua golongan untuk menerima setiap warga negara secara tulus tanpa mempedulikan agamanya. Meminjam istilah filsuf JJ Rousseau, sila pertama itu merupakan bagian "kontrak sosial" yang disepakati untuk mendirikan bangunan NKRI. Sebuah negara berbingkai Ketuhanan, tanpa dikotomi antara agama mayoritas- minoritas. Negara kebangsaan dalam bingkai kepercayaan kepada Tuhan tanpa membedakan agama yang dianut.

Bingkai negara Ketuhanan ternyata mampu selama lebih dari setengah abad memelihara harmoni dalam keragamanan komunitas beragama di Indonesia. Hanya sayang, bahwa harmoni itu belakangan ini terus diusik oleh kepentingan-kepentingan politik atau kepentingan-kepentingan lainnya yang partisan. Keresahan kelompok minoritas atas lahirnya berbagai Perda bernuansa Syariat Islam, sebenarnya keresahan umat mayoritas juga. Bahwa, kemurnian agama dapat ternoda oleh keterlibatan negara yang terlalu jauh di dalamnya. 
Secara lebih kusus lagi, sangat diperlukan adanya upaya regulasi kurikulum pesantren yang selama ini masih terkesan hanya "membela Tuhan" atau istilah lain teosentris menuju paradigma yang antroposentris. Proses perubahan tersebut harus bertahap dan secara pelan-pelan, karena sangat rentan akan adanya "kecurigaan" oleh kalangan pesantren. Selama ini pesantren mencoba untuk tetap bertahan dengan klurikulum lama yang sudah bertahun-tahun eksis dan sudah dirasa final. Namun pada dasarnya, perubahan paradigma yang lebih memberikan tempat untuk kajian antaragama menjadi keniscayaan.

Selama ini, ketika membahas hubungan antar agama masih terasa terbatas pada kajian nikah antaragama dan sedikit membahas tatacara hubungan dengan agama lain. Menjadi hal yang baik manakala pesantren lebih aktif untuk berperan menyongsong keberbedaan tersebut. Ajaran semacam tasamuh yang selama ini menjadi salah satu pilar pesantren perlu dielaborasi lebih dalam, sehingga benarbenar menemukan makna dan nilai terdalam dari ajaran tersebut. Terlebih lagi ajaran tasawuf yang sangat kental menyelimuti dunia pesantren, pada padasarnya menjadi salah satu pondasi utama dalam pengembangan pendidikan toleransi beragama di pesantren. Karena ajaran tasawuf pada dasarnya memberikan pemahaman akan pentingnya "memanusiakan manusia" dan berdampingan secara harmonis dengan semua makhluk Tuhan yang ada.

\section{Paradigma Inklusif dalam Pembelajaran di Pesantren}

Kontekstualisasi pesantren dengan masyarakat terlihat dengan upaya beberapa pesantren saat ini yang mencoba mengembangkan toleransi beragama di lembaganya. Pada dasarnya pesantren telah memiliki pondasi kuat guna penanaman toleransi beragama di tengah masyarakat. Pondasi tersebut diperoleh dari adanya pendidikan dan pengalaman nilai yang termaktub dalam karya para ulama dalam berbagai khasanah keilmuan kutub alshafra (kitab kuning) yang selama ini dikaji oleh dunia pesantren. Santri sebenarnya sudah banyak ditanamkan nilai seperti toleransi beragama, namun saat ini dirasa masih kurang dalam aplikasi kehidupan riil sehari-hari. Ajaran akan menghargai agama lain sudah sangat sering dikaji dan dipahami, namun jarang dicontohkan.

Nilai-nilai toleransi pada dasarnya sudah diletakkan oleh para ulama pesantren dalam berbagai keilmuan, misalnya saka tasawuf dan fiqih. Dibutuhkan pemahaman dan pemaknaan secara komprehensif dan integratif untuk dapat menggali dan kemudian mengejawentahkan dalam kehidupan sehari-hari. Sebagai contoh adanya konsep rahmatan li al-'alamin yang selama ini belum begitu banyak menyentuh keberagamaan manusia. Konsep itu sudah lama dipahami oleh santri, namun sementara ini belum mendapat porsi yang tepat terkait keberbedaan agama 
tersebut. Santri hanya disuguhkan pada konsep saling menghargai antara sesama umat beragama, tanpa adanya upaya bagaimana cara menghargainya secara riil kehidupan sehari-hari. Penghargaan terhadap orang lain akan semakin kuat manakala betul-betul dihadapkan pada konteks dan kondisi yang berbeda tersebut. Santri seyogyanya sering dikenalkan secara riil dengan eksistensi "yang berbeda" tersebut.

Agama seharusnya dapat menjadi pendorong bagi umat manusia untuk selalu menegakkan perdamian dan meningkatkan kesejahteraan bagi seluruh umat manusia dibumi ini. Sayangnya, dalam kehidupan yang sebenarnya, agama justru seringkali menjadi salah satu penyebab terjadinya kekerasan dan kehancuran umat manusia. Kenyataan pahit yang menyangkut kehidupan umat bergama ini dialamai oleh berbagai macam pemeluk agama dan terjadi diseluruh belahan dunia. Di Bosnia Herzegovina umat Islam dan Katolik saling membunuh, di Afrika tepatnya di Negeria sering terjadi perselisihan yang mengakibatkan tragedy berdarah antara umat Katolik dan Islam. Di Irlandia utara, umat Kristen dan Katolik sampai saat ini saling bermusuhan.

Di timur tengah, meskipun kekerasan yang timbul dikawasan ini ditengarai bukan disebabkan oleh perbedaan agama, akan tetapi kelompok-kelompok yang bersitegang justru mewakili tiga golongan masyarakat yang berbeda agama seperti Islam, Yahudi, dan Kristen. Juga wilayah kasmir, umat hindu dan Islam hingga sekarang saling melakukan kekerasan. ${ }^{38}$

Di Indonesia, menurut Sudarto ${ }^{39}$ kasus-kasus pertentangan antar agama juga kerap terjadi. Agama juga sering kali dapat menjadi pemicu timbulnya - percikanpercikan apill yang dapat menyebabkan konflik horizontal antar pemeluk agama, seperti yang terjadi di Ambon, maluku, kalaimantan (sambas) barat dan timur (sampit) bukan saja telah banyak merenggut korban jiwa yang sangat besar, akan tetapi juga telah menghancurkan ratusan tempat ibadah (baik geraja maupun masjid) terbakar dan hancur.

Setelah adanya kenyataan pahit yang demikian itu maka sangat perlu untuk membangun upaya-upaya prefentif agar masalah pertentangan agama tidak akan terulang lagi dimasa yang akan datang.

Sebagaimana yang di utarakan M. Ainul Yakin, ${ }^{40}$ bahwa saat ini dibutuhkan sebuah upaya mengintensifkan forum-forum dialog antar umat beragama dan aliran kepercayaan, mebangun pemahaman keagamaan yang lebih pluralis dan inklusif, serta memberikan pendidikan tentang pluralisme dan toleransi beragama melalui lemabaga-lembaga pendidikan terutama lembaga pendidikan agama yang dianggap menjadi sumber utama munculnya pemikiran beragama dinegeri ini, seperti pesantren atau sekolah telogi dan sebagainya.

${ }^{38}$ Alwi Sihab, Islam Inklusif, (Bandung : Mizan, 1998), 90.

${ }^{39}$ H. Sudarto, Konflik Islam Kristen; Menguak Akar Maslah Hubungan Antar Umat Beragama Di Indonesia, (Semarang: Putaka Riski Putera, 1999), 24.

40 M. Ainul Yaqin, Pendidikan Multikultural; Corss-Cultural Understanding Untuk Demokras dan Keadilani, (Yogyakarta: Pilar Media, 2005), 35. 
Dalam konteks ini menjadi penting dalam dunia pendidikan pesantren agar mengembangkan berbagai potensi yang dimilikinya untuk kemudian dapat dijadikan sebagai langkah paradigmatic sekaligus strategis bagi pencegahan dan penanganan timbulnya konflik dimasyarakat, baik konflik tersebut diakibatkan oleh perbedaan agama, konflik sara ataupun konflik-konflik kepetentingan lainnya, terutama konflik yang dapat menimbulkan terjadinya kekerasan.

Diakui atau tidak, yang menjadi salah satu penyebab utama terjadinya konflik di masyarakat yang selama ini adalah adanya paradigma keberagamaan yang masih eksklusif. ${ }^{41}$ Eksklusifisme masyarakat tersebut tampak dalam pola pikir beragama yang relatif masih dispariasitas, dan masih terdapat sekat-sekat primordialisme. Oleh karena itu, dibutuhkan sebuah paradigma baru dalam mengatur hubungan tersebut.

Muhammad $\mathrm{Ali}^{42}$ mengatakan, untuk mencegah agar pemahaman kemasyarakatan yang eksklusif ini tidak terus berkembang maka perlu diambil langkah preventif, yaitu membangun pemahaman kemasyarakatan yang lebih inklusiv dan humanis.

Paradigma kemasyarakatan yang inklusif disini memiliki makna dapat menerima pendapat dan pemahaman kelompok masyarakat lain yang memiliki basis suku, ras dan keagamaan yang berbeda.

Sikap inklusif akan pluralism ummat beragama merupakan suatu sikap kunci pembuka kedamaian dalam beragama, tanpa membuat kegaduhan atau pencampuradukan ajaran atau yang lebih dikenal dengan sinkretisme agama, ummat agama akan lebih humanis dalam menyikapi persoalan kehidupan sosial terutama yang bersangkut paut dengan agama itu sendiri.

Melalui hubungan baik dengan kekuatan yang diyakini oleh setiap kaum agamawan, setiap manusia akan merasa tenang dan damai. Kecemasan munculnya konflik dapat dikurangai dengan sikap inklusiftas beragama. ${ }^{43}$ Dan untuk itu kenapa manusia beragama, tiada lain adalah untuk mendapatkan ketenangan batin dalam menjalankan roda kehidupan yang heterogen. Manusia sebagai makhluk yang senantiasa dilingkupi rasa cemas dan penuh harap, sejatinya membutuhkan suatu kekuatan yang dapat menggiringnya pada kehidupan yang penuh dengan kebahagiaan, yakni Tuhan sebagai tujuan akhir dari manusia.

Sedemikian tingginya Tuhan memberikan kemerdekaan kepada manusia untuk beragama, ${ }^{44}$ ini dapat terlihat dalam Q.s. al-Kaafirun ayat keenam yang menyebutkan bahwa

“...untukmu agamamu, untukku agamaku...”,

${ }^{41}$ Paul, J Gift, Problems of Religious Diversity, (Malden, MA: Blackwell Publishing, 2001), 21.

${ }^{42}$ Muhammad Ali, Shift Paradigm; Pemahaman Agama, Kompas, edisi 7 Oktober 2003

${ }^{43}$ Komarudin Hidayat, Agama Punya Seribu Nyawa, (Jakarta; Noura, 2012), 17

${ }^{44}$ Ibid., 56 
Hal ini merupakan pertanda bahwa Tuhan telah menjaga nilai dari masingmasing agama dan manusia dengan akal dan hatinya berhak untuk beragama menurut keyakinannya dengan maksud beribadah semata-mata karena Tuhan yang satu.

\section{E. Simpulan}

Dari penjelasan tentang pendidikan inklusif dan dinamika pesantren tersebut, dapatlah disimpulkan sebagai berikut: pertama, pesantren secara historis-faktual telah mengalami pergeseran konstruks, dengan berbagai berbedaan antara pesantren satu dengan yang lainnya, menuju pada eksistensi yang semakin berkembang seiring dinamika dan perkembangan masa dan lingkungan sekitarnya.

Salah satu perkembangan tersebut ialah pada sisi hubungan beragama. Pesantren saat ini telah mulai memiliki karakter yang inklusif, walaupun sebenarnya upaya itu sudah terbentuk dari masa-masa pesantren pada masa perkembangannya. Pesantren telah berupaya sedemikian rupa untuk mampu turut serta dalam pengembangan kehidupan bergama yang lebih harmonis, dengan memberikan pemahaman, pembiasaan, serta pengkulturan budaya toleransi kepada para santri dan civitas pesantren.

Model pesantren yang bernuansa bahkan berkonstruks inklusif seperti ini yang diharapkan akan memberikan sumbangsih terciptanya kerukunan hidup beragama yang baik di negeri ini. Pemaknaan kembali konsep seperti ajaran rahmatan li al- 'alamin dan konsep ukhuwwah pada santri menjadi penting untuk dilakukan sebagai salah satu contoh upayanya adalah penguatan toleransi bergama di pesantren.

\section{Daftar Pustaka}

Ali, Hussein 2016. Jawa Barat Jadi Provinsi Tertinggi Kasus Radikalisme dan Intoleransi, Radar

Cirebon,

Ali, Muhammad. 2003. Shift Paradigm; Pemahaman Agama, Kompas, edisi 7 Oktober 2003

Azra, Azyumardi. 1999. Pendidikan Islam: Tradisi dan Modernisasi Menuju Milenium Baru. Jakarta:

Logos Wacana Ilmu.

Bekker, Anton dan Achmad Charis Zubair. 1990. Metodologi Penelitian Filsafat, (Yogjakarta: Kanisius.

Black, Antony. 2000. Pemikiran Politik Islam dari masa Nabi hingga masa kini. Jakarta: PT. Serambi

Ilmu Semesta.

Dhofier, Zamakhsyari. 1985. Tradisi Pesantren: Studi Tentang Pandangan Hidup Kyai. Jakarta; LP3ES.

Fadjar, Malik. 1998. Visi Pembaruan Pendidikan Islam. Jakarta: LP3NI. 
H. Sudarto, 1999. Konflik Islam Kristen; Menguak Akar Maslah Hubungan Antar Umat Beragama di

Indonesia. Semarang: Putaka Riski Putera.

Hasbullah. 1999. Sejarah Pendidikan Islam di Indonesia: Lintasan Sejarah Pertumbuhan dan

Perkembangan. Jakarta; PT. Raja Grafindo Persada.

Hidayat, Komarudin. 2012. Agama Punya Seribu Nyawa. Noura Books. Jakarta

Lucito, Ahmad. 1996. "Filsafat Nilai dalam Islam" dalam Chabib Thoha et.al, Reformulasi Filsafat

Pendidikan Islam. 1998. Yogyakarta: Pustaka Pelajar dan FT. IAIN Walisongo. Semarang.

M. Shodiq. 2011. Pesantren dan Perubahan Sosial. UIN Sunan Ampel Surabaya; Jurnal Falasifa.

Madjid, Nurcholish. 1987. Islam Kemodernan dan Keindonesiaan. Jakarta: Mizan. 1997. Bilik-bilik Pesanren: Sebuah Potret Perjalanan. Jakarta;

Paramdina.

2003. Islam Agama Kemanusiaan. Jakarta: Paramadina.

Manpan Drajat, M. R. E. (2015). Etika Ptrofesi Guru. Alfabeta.

Muhamad Ridwan Effendi, Rudi M. Barnansyah, S. N. (2019). Model Pendidikan

Inklusif Pondok Pesantren. Laboratorium PAI FIS UNJ.

https://seminars.unj.ac.id/icic/

Effendi, M. R., Barnansyah, R. M., \& Nurpratiwi, S. (2019). MODEL PENDIDIKAN PONDOK PESANTREN INKLUSIF. PROCEEDING BOOK.

Effendi, M. Ridwan dan Manpan Drajat. Etika Profesi Guru. Cet. I: Bandung; Alfabeta, 2014.

Mastuhu, 1997. Dinamika Sistem Pendidikan Pesantren. Jakarta: INIS.

Nurdin Syafi'i, HM. 2008. "Kontribusi Pesantren dalam Mencetak Generasi Mandiri”,

Tesis. Yogyakarta: Pascasarjana UIN Sunan Kalijaga.

Paul, J Gift. 2001. Problems of Religious Diversity. Malden, MA: Blackwell Publishing.

Poerbawatja, Soegarda. 1976. Ensiklopedi Pendidikan. Jakarta: Gunung Agung.

Putra, Hermansyah. 2010. "Pondok Pesantren dan Tantangan Globalisasi", Tesis. Yogyakarta:

Pascasarjana UIN Sunan Kalijaga.

Sihab, Alwi. 1998. Islam Inklusif. Bandung: Mizan.

Sobur, Alex. 2004. Analisis Teks Media: Suatu Pengantar untuk Analisis Wacana, Analisis Semiotik dan

Analisis Framing. Bandung: PT. Remaja Rosdakarya.

Steenbrink, Karel A. 1982. Pesantren Madrasah Sekolah. Jakarta: LP3ES.

Sukardi. 2007. Metodologi Penelitian Pendidikan: Kompetisi dan Prakteknya. Jakarta: PT. Bumi

Aksara. 
Tim penyusun Kamus Pusat Pembinaan dan Pengembangan Bahasa, 1990. Kamus Besar Bahasa

Indonesia, cet. 3 .

Wahid, Abdurrahman. 1995. "Pesantren sebagai Kultur”, dalam Dawam Raharjo (ed.), Pesantren dan

Pembaharuan. Jakarta: LP3ES. 2001. Menggerakkan Tradisi Pesantren.Jogyakarta: LKIS.

Wahjoetomo, 1997. Perguruan Tinggi Pesantren, Pendidikan Alternatif Masa Depan. Jakarta: Gema

Insani Press.

Yaqin, M. Ainul. 2005. Pendidikan Multikultural; Corss-Cultural Understanding Untuk Demokras dan

Keadilani. Yogyakarta: Pilar Media.

Yusuf Ali, Abdullah. 1993. Qur"an dan Tafsirnya, terj. Ali Audah. Jakarta: Pustaka Firdaus.

Ziemek, Manfred. 1986. Pesantren Dalam Perubahan Sosial, terj. Butche B. Soendjojo, cet I. Jakarta:

P3M 